\title{
Asupan isoflavon yang tinggi meningkatkan kepadatan tulang pada perempuan pascamenopause
}

\author{
Nyiayu Alisa Mahira Luthfie ${ }^{1}$, Elly Herwana²
}

\begin{abstract}
ABSTRAK
\section{LATAR BELAKANG}

Penderita osteoporosis di Indonesia didapatkan pada 32.3\% perempuan yang berusia di atas 50 tahun. Banyak faktor mempengaruhi proses osteoporosis dan hormon estrogen dianggap berpengaruh terhadap terjadinya osteoporosis pada perempuan pascamenopause sehingga didapatkan prevalensi osteoporosis yang lebih tinggi. Isoflavon mempunyai struktur molekul yang mirip dengan estrogen dan menunjukkan efek sebagai fitoestrogen, diketahui banyak terdapat pada makanan yang berasal dari kacang kedelai. Makanan yang kaya isoflavon dapat memengaruhi proses remodelling tulang. Penelitian ini bertujuan untuk menilai hubungan antara asupan isoflavon dan kepadatan tulang pada perempuan pascamenopause.
\end{abstract}

\section{METODE}

Penelitian ini merupakan penelitian analitik observasional dengan desain potong lintang dan menggunakan perempuan pascamenopause sebagai subjek penelitian. Asupan isoflavon dinilai dengan menggunakan Food Frequency Questionnaire (FFQ). Pengukuran terhadap kepadatan tulang dilakukan pada tulang kalkaneus dengan menggunakan alat Calcaneus Quantitative Ultrasound (QUS).

\section{HASIL}

Sebanyak 92 perempuan pascamenopause memenuhi kriteria inklusi dan berpartisipasi sebagai subjek penelitian. Hasil penelitian menunjukkan distribusi asupan isoflavon pada subjek didapatkan asupan isoflavon tinggi sebanyak 42 (45.7\%) subjek, sedang sebanyak 31 (33.7\%) subjek, dan 19 (20.6\%) asupan isoflavon rendah. Distribusi kepadatan tulang pada perempuan pascamenopause didapatkan 18 subjek (19.6\%) dengan kepadatan tulang normal, osteopenia sebanyak 45 (48.9\%), dan 29 subjek (31.5\%) mengalami osteoporosis. Analisis statistik menunjukkan terdapat hubungan bermakna antara asupan isoflavon dan kepadatan tulang pada perempuan pascamenopause $(\mathrm{p}=0.001 ; \mathrm{p}<0.05)$.

\section{KESIMPULAN}

Penelitian ini menunjukkan bahwa terdapat hubungan yang bermakna antara asupan isoflavon dan kepadatan tulang pada perempuan pascamenopause.

Kata kunci: isoflavon, kepadatan tulang, pascamenopause
${ }^{1}$ Program Studi Kedokteran, Fakultas Kedokteran Universitas Trisakti, Indonesia

${ }^{2}$ Departemen Farmakologi dan Farmasi Kedokteran, Fakultas Kedokteran Universitas Trisakti, Indonesia

\section{Korespondensi:}

Elly Herwana

Departemen Farmakologi dan Farmasi Kedokteran, Fakultas Kedokteran Universitas Trisakti, Indonesia

Jalan Kyai Tapa No. 260, Grogol, Jakarta Barat

Email: elly.herwana@trisakti.ac.id

J Biomedika Kesehat 2019;2(4):132137

DOI: 10.18051/JBiomedKes.2019. v2.132-137

pISSN: 2621-539X / eISSN: 2621-5470

Artikel akses terbuka (open access) ini didistribusikan di bawah lisensi Creative Commons Attribution 4.0 International (CC-BY 4.0) 


\section{ABSTRACT}

\section{High isoflavone intake increase bone density in postmenopausal women}

\section{BACKGROUND}

Osteoporosis sufferers in Indonesia is $32.3 \%$ in women aged over 50 years. Many factors affect the process of osteoporosis and estrogen hormone was considered to influence the occurrence of osteoporosis in postmenopausal women so that a higher prevalence of osteoporosis is obtained. Isoflavones have a molecular structure similar to estrogen and show effects as phytoestrogens, known to be abundant in foods derived from soybeans. Foods that are rich in isoflavones can affect the bone remodeling process. This study aims to assess the relationship between isoflavone intake and bone density in postmenopausal women.

\section{METHODS}

This study was an observational analytic study with a cross-sectional design and used postmenopausal women as research subjects. Isoflavone intake was assessed using the Food Frequency Questionnaire (FFQ). Measurement of bone density was performed on os Calcaneus using Calcaneus Quantitative Ultrasound (QUS).

\section{RESULT}

A total of 92 postmenopausal women met to the inclusion criteria and participated as research subjects. The results showed the distribution of isoflavone intake in subjects obtained high isoflavone intake by 42 subjects $(45.7 \%)$, medium intake by 31 subject (33.7\%), and 19 subjects $(20.6 \%)$ had low isoflavone intake. Bone density distribution in postmenopausal women found 18 subjects $(19.6 \%)$ with normal bone density, 45 subjects with osteopenia $(48.9 \%)$, and 29 subjects $(31.5 \%)$ had osteoporosis. Statistical analysis showed a significant relationship between isoflavone intake and bone density in postmenopausal women $(p=0.001 ; p<0.05)$.

\section{CONCLUSION}

This study shows that there is a significant relationship between isoflavone intake and bone density in postmenopausal women.

Keywords: isoflavones, bone density, postmenopausal

\section{PENDAHULUAN}

Osteoporosis merupakan salah satu penyakit degeneratif yang berkaitan dengan proses penuaan, ditandai dengan massa tulang yang rendah dan penurunan mikroarsitektur jaringan tulang sehingga meningkatkan risiko fraktur. ${ }^{(1,2)}$ Perhimpunan Osteoporosis Indonesia melaporkan bahwa prevalensi osteoporosis pada perempuan yang berusia di atas 50 tahun adalah 32.3\% sedangkan pada laki-laki di usia yang sama $28.8 \%{ }^{(3)}$ Risiko pada laki-laki berusia diatas 50 tahun 4 kali lebih rendah dibandingkan dengan perempuan pada usia yang sama. ${ }^{(4)}$ Angka kejadian osteopenia di Provinsi Jawa Barat mencapai $34.6 \%$ dan osteoporosis $22.2 \%$. ${ }^{(1)} \mathrm{WHO}$ melaporkan bahwa komplikasi dari osteoporosis yang menimbulkan kecacatan seumur hidup sebanyak $50 \%$ dan angka kematian mencapai $30 \%$ pada tahun pertama akibat immobilisasi. ${ }^{(5)}$

Banyak faktor yang dapat mempengaruhi terjadinya osteoporosis. Perempuan pascamenopause mempunyai insiden penurunan massa tulang yang lebih tinggi dibandingkan lakilaki dan peran estrogen dianggap berperan atas proses terjadinya osteoporosis. Isoflavon memiliki struktur kimia dan fungsi yang menyerupai hormon estrogen, komponen ini disebut fitoestrogen yang biasa ditemukan dalam kacang kedelai dan pada produk olahan kedelai yang tidak melalui proses fermentasi. ${ }^{(6,7)}$ Isoflavon merupakan salah satu jenis fitoestrogen yang bekerja sebagai Selective Estrogen Receptor Modulator (SERM) dengan efek menguntungkan pada tulang yang menyerupai efek raloxifene. ${ }^{(8,9)}$ Isoflavon berperan dalam menstimulasi pembentukan tulang dan menghambat reabsorpsi tulang, sehingga dengan mekanisme tersebut isflavon dapat menjaga kesehatan tulang. Hasil penelitian menunjukkan bahwa makanan yang kaya isoflavon dapat menurunkan risiko pengeroposan tulang pada perempuan pascamenopause dan perimenopause, sehingga angka kejadian osteoporosis didapatkan lebih rendah dibandingkan dengan perempuan pascamenopause yang mengkonsumsi pola makanan barat dengan kandungan isoflavon yang rendah. ${ }^{(7)}$ Hasil studi epidemiologi menyebutkan rendahnya insiden osteoporosis pada perempuan pascamenopause di Asia, berkaitan dengan asupan makanan yang berbahan dasar kedelai. Rerata asupan isoflavon dari berbagai makanan kedelai pada perempuan di Asia adalah 25-50 mg/hari, sedangkan rerata asupan isoflavon perempuan Kaukasian kurang dari $2 \mathrm{mg} /$ hari. $^{(10)}$ Hasil 
penelitian sebelumnya menunjukkan bahwa perempuan pascamenopause yang mengkonsumsi isoflavon $<35 \mathrm{mg} /$ hari meningkatkan risiko rendahnya kepadatan tulang sebesar 7.9 kali. ${ }^{(6)}$ Hasil penelitian lain menunjukkan bahwa asupan makanan kaya isoflavon sebanyak $40 \mathrm{mg} /$ hari selama 8 minggu pada perempuan pascamenopause dapat menurunkan risiko pengeroposan tulang. (11) Hasil studi lain mendukung adanya efek yang menguntungkan dari isoflavon dalam mencegah dan mengurangi risiko pengeroposan tulang pada perempuan pascamenopause secara signifikan. ${ }^{(9,12)}$ Hal ini mengindikasikan bahwa isoflavon dapat dijadikan alternatif terapi yang alami untuk substitusi estrogen pada perempuan pascamenopause. ${ }^{(7)}$

Angka kejadian osteoporosis yang masih tinggi di Indonesia dan penelitian mengenai keterkaitan massa tulang dan asupan isoflavon masih sedikit. Penelitian ini bertujuan untuk menilai hubungan antara asupan isoflavon dan kepadatan tulang padaperempuan pascamenopause

\section{METODE}

Penelitian ini menggunakan analitik observasional dengan pendekatan desain cross sectional yang telah dilakukan pada bulan Juli sampai November 2017 di kelurahan Sudimara Barat di Tangerang, Banten. Penelitian ini melibatkan sejumlah subjek dengan kriteria inklusi perempuan pascamenopause alamiah di Kelurahan Sudimara Barat, mampu berjalan dan berkomunikasi, serta bersedia untuk menandatangani informed concent. Perempuan yang mengalami menopause non alamiah, punya riwayat menderita penyakit tiroid atau paratiroid, mendapat terapi sulih hormon, kortikosteroid, atau mengonsumsi suplemen yang mengandung isoflavon, dimasukkan sebagai kriteria eksklusi. Perhitungan jumlah sampel dilakukan secara finitinfinit dengan menggunakan rumus:

$$
N=Z \alpha^{2}(p x q) / d^{2}
$$

Prevalensi osteoporosis pada perempuan pascamenopause besarnya $32.2 \%$, pada tingkat kemaknaan 95\% dan keakuratan sebesar 0.05, maka didapatkan besar sampel adalah 336. Jumlah perempuan pascamenopause di kelurahan tersebut adalah 100 orang dan dengan memperhitungkan dropout sebesar $15 \%$, maka besar sampel minimal yang diperlukan menjadi 89 subjek perempuan pascamenopause. Pemilihan subjek penelitian dilakukan secara consecutive non-random sampling.

Penelitian ini diperoleh dari data primer berdasarkan hasil pengukuran langsung dari subjek. Asupan isoflavon dinilai dengan Food Frequency Questionnaire (FFQ). Subjek diminta untuk mencatat jenis makanan yang dikonsumsi untuk disetarakan dengan jumlah asupan isoflavon total per hari. Asupan isoflavon ini dikelompokkan sebagai asupan rendah $(\leq 10.97 \mathrm{mg} /$ hari $)$, sedang (10.97-26.73 mg/hari), dan asupan tinggi ( $\geq 26.74$ $\mathrm{mg} /$ hari). Kepadatan tulang diukur dengan alat Calcaneus Quantitative Ultrasound (QUS). Hasil pengukuran kepadatan tulang dikelompokkan menjadi normal ( $\mathrm{T}$ score $\geq-1$ ), osteopenia ( $\mathrm{T}$ score $-1 \mathrm{sd}>-2.5$ ) dan osteoporosis ( $\mathrm{T}$ score $\leq$ $-2.5)$.

Analisis data yang digunakan dalam penelitian ini adalah analisis univariat dan bivariat yang dilakukan secara bertahap. Analisis univariat menampilkan data deskriptif analitik yang menggambarkan distribusi dari tiap variabel penelitian yaitu usia, lama menopause, asupan isovlavon, dan kepadatan tulang. Uji statistik bivariat Chi-Square dilakukan untuk menilai hubuangan anatara kedua variabel penelitian. Tingkat kemaknaan yang digunakan besarnya 0.05 .

\section{HASIL}

Tabel 1. Distribusi karakteristik subjek dan variabel penelitian $(n=92)$

\begin{tabular}{lcc}
\hline \multicolumn{1}{c}{ Variabel } & n & \% \\
\hline Usia & 6 & \\
$<48$ tahun & 86 & 6.5 \\
$\geq 48$ tahun & & 93.5 \\
Lama menopause & 44 & \\
$\quad<5$ tahun & 48 & 47.8 \\
$\geq 5$ tahun & & 52.2 \\
Asupan isoflavon & 19 & \\
Rendah & 31 & 20.6 \\
Sedang & 42 & 33.7 \\
Tinggi & & 45.7 \\
Kepadatan tulang & 18 & \\
$\quad$ Normal & 45 & 49.6 \\
Osteopenia & 29 & 31.5 \\
Osteoporosis & & \\
\hline
\end{tabular}

Penelitian ini telah dilaksanakan pada bulan Juli sampai dengan November 2017 di kelurahan Sudimara Barat, Kota Tangerang dan sebanyak 92 perempuan pascamenopause yang 
Tabel 2. Hubungan asupan isoflavon dan kepadatan tulang $(\mathrm{n}=92)$

\begin{tabular}{lcccc}
\hline Variabel & \multicolumn{3}{c}{ Kepadatan tulang } & p \\
\hline $\begin{array}{c}\text { Asupan Isoflavon } \\
\text { Rendah }\end{array}$ & $\begin{array}{c}\text { Normal } \\
(\mathbf{n} / \%)\end{array}$ & $\begin{array}{c}\text { Osteoporosis } \\
(\mathbf{n} / \%)\end{array}$ & $\begin{array}{c}\text { Total } \\
(\mathbf{n} / \%)\end{array}$ & $0.001^{*}$ \\
Tinggi & $23(52.3)$ & $21(44.7)$ & $44(100.0)$ & \\
\hline
\end{tabular}

*Uji Fisher (berbeda bermakna; $\mathrm{p}<0.05$ )

dilibatkan sebagai subjek penelitian.

Usia subjek penelitian dibedakan menjadi

2 kelompok dengan titik potong 48 tahun, sesuai dengan rerata usia menopause perempuan di Indonesia. Distribusi usia subjek mayoritas ada di atas usia $\geq 48$ tahun yaitu sebanyak 86 (93.5\%) subjek, sedangkan usia $<48$ tahun sebanyak enam (6.5\%) subjek. Lama menopause menggunakan titik potong 5 tahun sesuai dengan kriteria menopause awal dan lanjut dan didapatkan distribusi yang hampir seimbang yaitu menopause $<5$ tahun sebanyak $44(47.8 \%)$ dan $\geq 5$ tahun ada 48 (52.2\%) subjek penelitian (Tabel 1).

Hasil pengukuran kepadatan tulang dikelompokkan menjadi tiga kategori yaitu kategori normal sebanyak 18 (19.6), osteopenia sebanyak 45 (48.9\%), dan 29 (31.5\%) subjek telah mengalami osteoporosis. Asupan isoflavon dikelompokkan menjadi tiga kategori yaitu asupan isoflavon tinggi sebanyak 42 (45.7\%) subjek, sedang sebanyak 31 (33.7\%) subjek, dan 19 (20.6\%) asupan isoflavon rendah, menunjukkan mayoritas subjek termasuk kategori asupan isoflavon tinggi dan sedang (Tabel 1).

Analisis hubungan asupan isoflavon dan kepadatan tulang dilakukan dengan uji Fisher, asupan isoflavon dibedakan atas asupan rendah dan asupan tinggi, kepadatan tulang dibedakan normal dan osteoporosis. Hasil uji Fisher menunjukkan bahwa terdapat hubungan bermakna antara asupan isoflavon dan kepadatan tulang $(\mathrm{p}=0.001$; $\mathrm{p}<0.05)$ (Tabel 2).

Hasil analisis subjek dengan lama menopause, jumlah subjek dengan lama menopause $<5$ tahun dan lama menopause $\geq$ 5 tahun menunjukkan jumlah yang tidak jauh berbeda. Pada kedua kelompok menunjukkan distribusi kepadatan tulang yang setara, yaitu jumlah tertinggi adalah pada kelompok osteopenia, diikuti kelompok osteoporosis, dan yang terendah adalah kepadatan tulang yang normal. Tidak tampak kecenderungan peningkatan frekuensi osteoporosis pada kedua kelompok lama menopause (Tabel 3).

\section{PEMBAHASAN}

Hasil penilaian terhadap asupan isoflavon pada subjek, didapatkan terbanyak adalah pada kelompok asupan tinggi yaitu sebanyak 42 (45.7\%) subjek dan sedang 31 (33.7\%) subjek, yang menunjukkan asupan rendah hanya 19 (20.6\%). Hasil ini sesuai dengan studi epidemiologi yang menyebutkan bahwa rata-rata asupan isoflavon pada perempuan pascamenopause di Asia dari berbagai makanan kedelai mengandung $25-50 \mathrm{mg} /$ hari $^{\left({ }^{(10)}\right.}$

Hasil pengukuran kepadatan tulang pada subjek perempuan pasca menopause pada penelitian ini, didapatkan bahwa terbanyak adalah tergolong pada osteopenia. Hal ini sesuai dengan data yang dilaporkan oleh Departemen Kesehatan, bahwa prevalensi osteopenia di Indonesia mencapai $41.7 \%$ dan osteoporosis mencapai $10.3 \% \cdot{ }^{(5)}$ Hasil penelitian ini didapatkan hubungan yang bermakna antara asupan isoflavon dan kepadatan tulang $(\mathrm{p}=0.001 ; \mathrm{p}<0.05)$. Penelitian sebelumnya mendapatkan bahwa faktor risiko paling berpengaruh pada kepadatan tulang rendah

Tabel 3. Hubungan lama menopause dan kepadatan tulang $(\mathrm{n}=92)$

\begin{tabular}{ccccc}
\hline Variabel & \multicolumn{3}{c}{ Kepadatan tulang } \\
\hline & $\begin{array}{c}\text { Normal } \\
(\mathbf{n} / \mathbf{\%})\end{array}$ & $\begin{array}{c}\text { Osteopenia } \\
\mathbf{( n / \% )}\end{array}$ & $\begin{array}{c}\text { Osteoporosis } \\
(\mathbf{n} / \mathbf{\%})\end{array}$ & $\begin{array}{c}\text { Total } \\
(\mathbf{n} / \mathbf{\%})\end{array}$ \\
$\begin{array}{c}\text { Lama menopause } \\
<5 \text { tahun }\end{array}$ & $9(20.4 \%)$ & $23(52.3)$ & $12(27.3)$ & $44(100.0)$ \\
$\geq 5$ tahun & $9(18.8)$ & $22(45.8)$ & $17(35.4)$ & $48(100.0)$ \\
\hline
\end{tabular}


pada wanita pascamenopause yaitu asupan isoflavon kedelai yang kurang, penderita diabetes melitus, dan lama menopause $>10$ tahun. $^{(6)}$ Konsumsi isoflavon yang rendah meningkatkan risiko rendahnya kepadatan tulang sebesar 7.9 kali. Penelitian lainnya melaporkan bahwa asupan makanan kaya isoflavon dapat mencegah penurunan massa tulang, yang ditandai dengan penurunan biomarker metabolisme tulang. (11) Meta-analisis yang dilakukan peneliti lain mendapatkan bahwa isoflavon yang tinggi secara signifikan meningkatkan densitas mineral tulang sebanyak 54\% dan menurunkan marker pengeroposan tulang di urin (urinary DPD). ${ }^{(9)}$ Hasil studi lain juga melaporkan bahwa isoflavon dapat mencegah osteoporosis pada perempuan pascamenopause dan meningkatkan kekuatan tulang sehingga menurunkan risiko fraktur. ${ }^{(13,14)}$

Penurunan massa tulang merupakan kondisi yang dipengaruhi banyak faktor, meningkat seiring dengan pertambahan usia dan lama menopause, merokok, aktivitas fisik, penggunaan kortikosteroid indeks massa tubuh, dan riwayat fraktur maternal. ${ }^{(15)}$ Evaluasi terhadap hubungan antara lama menopause dan kepadatan tulang yang dilakukan pada penelitian ini, didapatkan bahwa tidak tampak kecenderungan peningkatan frekuensi osteoporosis pada perempuan pascamenopause $<5$ tahun bilamana dibandingkan lama menopause $\geq 5$ tahun. Hasil penelitian ini tidak sejalan dengan penelitian yang melaporkan bahwa usia menopause merupakan salah satu faktor risiko terhadap rendahnya densitas massa tulang. ${ }^{(15)}$ Beberapa studi lain melaporkan bahwa osteoporosis bukan merupakan penyakit yang disebabkan oleh penuaan, melainkan penyakit yang meningkat kejadiaannya bersamaan dengan penuaan. $^{(16,17)}$ Osteoporosis juga dapat dijumpai pada usia muda seperti pada idiopathic juvenile osteoporosis, sementara pada kasus centenarians (usia >100 tahun) didapatkan bahwa mereka tidak mengalami fraktur. ${ }^{(17)}$ Hasil studi lain juga melaporkan bahwa terdapat gen spesifik yang turut berperan pada proses penurunan massa tulang dan menyebabkan osteoporosis. ${ }^{(18-20)}$

Penelitian ini mempunyai keterbatasan yaitu pengukuran terhadap kepadatan tulang dilakukan dengan menggunakan Calcaneus Quantitative Ultrasound (QUS) dan tidak menggunakan dual-energy X-ray absorptiometry
(DXA) yang merupakan gold standard pengukuran kepadatan tulang. Penelitian ini juga tidak mengukur isoflavon dalam darah yang memberikan gambaran lebih akurat terhadap asupan isoflavon. Penelitian ini juga tidak memperhitungkan faktor perancu seperti asupan kalsium dan kafein. ${ }^{(21)}$

\section{KESIMPULAN}

Asupan isoflavon yang lebih tinggi dapat menghambat penurunan kepadatan tulang pada perempuan pascamenopause. Perlu dilakukan penelitian lebih lanjut dengan desain eksperimental dan menggunakan metode pengukuran yang sesuai gold standard untuk setiap variabel.

\section{UCAPAN TERIMA KASIH}

Terima kasih kepada perempuan pascamenopause yang telah bersedia berpartisipasi dalam penelitian ini, juga kepada kepala Puskesmas Ciledug, Tangerang, serta semua pihak yang telah membantu hingga penelitian ini dapat terselesaikan.

\section{KONFLIK KEPENTINGAN}

Para peneliti tidak memiliki konflik kepentingan pada penelitian ini.

\section{KONTRIBUSI KEPENGARANGAN}

NAML dan EH berkontribusi pada penulisan naskah, pengumpulan, dan analisis data. EH berkontribusi pada perbaikan naskah. Semua penulis telah membaca dan memberikan persetujuannya.

\section{REFERENSI}

1. Prihatini S, Mahirawati VK, Jahari AB, Sudiman H. Faktor determinan risiko osteoporosis di tiga provinsi di Indonesia. Media Litbang Kesehatan 2010;20(2):91-9.

2. Mardiyah S, Sartika RAD. Gangguan kepadatan tulang pada orang dewasa di daerah urban dan rural. Jurnal Kesehatan Masyarakat Nasional 2014;8(6):272-8.

3. Pusat Data dan Informasi Kementerian Kesehatan RI. Data dan kondisi penyakit osteoporosis di Indonesia. Infodatin 2015:1-5.

4. International Osteoporosis Foundation. The Asia-Pacific regional audit epidemiology, costs $\&$ burden of osteoporosis in 2013. Asia Pacific regional audit 2013:56-60.

5. Kementerian Kesehatan Republik Indonesia. Kemenkes RI ajak masyarakat lakukan pencegahan os te o orosis. Updated October 15,2012 [cited 2017 Apr 26]. Available from: http://www. 
depkes.go.id/article/print/2083/kemenkes-ri-ajakmasyarakat-lakukan- pencegahan-osteoporosis. html.

6. Prabaningrum N, Dieny FF. Asupan isoflavon kedelai kurang sebagai faktor risiko kepadatan tulang rendah pada wanita pascamenopause. Journal of Nutrition College 2014;3(4):807-16.

7. Messina MJ, Wood CE.Soy isoflavones, estrogen therapy, and breast cancer risk: analysis and commentary. BMC Nutr 2008;7:17doi:10.1186/1475-2891-7-17.

8. Tai TY, Tsai KS, Tu ST, Wu JS, Chang CI, Chen $\mathrm{CL}$, et al. The effect of soy isoflavone on bone mineral density in postmenopausal taiwanese women with bone loss. Osteoporosis Int. 2011;23:1571-80.

9. Wei P, Liu M, Chen Y, Chen D. Systematic review of soy isoflavone supplements on osteoporosis in women. Asian Pac J Trop Med 2012:243-8.

10. Kridawati A. Pemanfaatan isoflavon untuk kesehatan. Jurnal Respati 2011;1(1):71-80.

11. Xiao CW. Health effects of soy protein and isoflavones in humans. J Nutr 2008;138:1244-9.

12. Bhagwat S, Haytowitz DB, Holden JM. USDA database for the isoflavone content of selected foods, release 2.0. U.S: Department of Agriculture; 2008.

13. Taku K. Osteoporosis; university of minnesota publishes research in osteoporosis.

14. Women's Health Weekly Atlanta 2012:4006.

15. Omoni AO, Aluko RE. Soybean foods and their benefits : potential mechanisms of action. Nutrition reviews 2005;63(8):272-83.

16. Nahas E, Kawakami MS, Nahas-Neto J, et al. Assessment of risk factors for low bone mineral density in Brazilian postmenopausal women. Climacteric 2011;14:220-7.

17. Boskey AL, Coleman R. Critical reviews in oral biology and medicine: Aging and bone. J Dent Res2010;89(12):1333-48.

18. Mellibovsky L, Bustamante M, Lluch P, Nogues $\mathrm{X}$, Grinberg D, Balcells S, et al. Bone mass of a 113-year-old man. J Gerontol A Biol Sci Med Sci 2010;62:794-5.

19. Richards JB, Kavvoura FK, Rivadeneira F, Styrkarsdottir U, Estrada K, Halldorsson BV, et al. Collaborative meta-analysis: associations of 150 candidate genes with osteoporosis and osteoporotic fracture. Ann Intern Med 2009;151:528-37.

20. Rauch F, Travers R, Norman ME, Taylor A, Parfitt AM, Glorieux FH. The bone formation defect in idiopathic juvenile osteoporosis is surfacespecific. Bone 2002; 31:85-9.

21. Płudowski P, Lebiedowski M, Olszaniecka M, Marowska J, Matusik H, Lorenc RS. Idiopathic juvenile osteoporosis - an analysis of the musclebone relationship. Osteoporos Int 2006;17:168190 .

22. Hayati S, Herwana E. Peningkatan asupan kalsium menghambat penurunan kepadatan tulang pada perempuan pascamenopause. J Biomedika Kesehat 2018;1:145-51. 